\title{
Isolation of Thermostable Protease Producing Bacteria from the Microbial Mats
}

\author{
*Malathi, $\mathbf{M}^{1}$ and Latha, $\mathrm{D}^{2}$ \\ ${ }^{1}$ Research scholar, Division of Microbiology, School of Biological Sciences, \\ CMS College of Science and Commerce, Coimbatore, Tamil Nadu, India \\ mals17819@gmail.com, 9994561177 \\ ${ }^{2}$ Associate Professor, Division of Microbiology, School of Biological Sciences, \\ CMS College of Science and Commerce, Coimbatore, Tamil Nadu, India \\ lathagangolly@ rediffmail.com, 9486240862
}

*Corresponding author details; 


\section{ABSTRACT}

As thermostable protease has more commercial value in different industries, the aim of this study was to search for such an enzyme producing bacteria from the microbial mats. Investigation was continued on the isolate for its ability to produce mass amount of enzyme and its activity under suitable optimized conditions. Different parameters including cheap carbon and nitrogen substrates, inoculum size and temperature was selected to optimize the enzyme production conditions. Initially five different isolates from two microbial mats collected from different sources were analyzed for its ability to produce thermostable protease after exposing to higher temperature incubation conditions. Test culture tentatively named as $1 \mathrm{~F}$ from microbial mat-1 was selected as more enzyme producer among the ten isolates. The organism was selected based on the zone of clearance on skim milk agar by the isolate, that indicating more protease production. Under each optimization parameter, each type of carbon (Lactose), and nitrogen (yeast extract) source showed more enzyme production and activity respectively. About $1 \%$ inoculum size and a thermostable temperature of $45^{\circ} \mathrm{C}$ produced significant amount of enzyme and its activity. The obtained results emphasized the need for thermostable protease for different commercial industries in the existing and near future.

Keywords: Thermostable, Protease, Optimization, Microbial mat, Enzyme activity. 


\section{INTRODUCTION}

Microbial mats contain diverse populations of prokaryotic organisms as well as eukaryotic organisms. The bacterial communities are spatially arranged in ways that facilitate metabolic cooperation [1] (Cristina M.Prieto-Barajas et al., 2018). Organisms associated with these mats can thrive on extreme conditions such as a high degree of water salinity, high temperatures and/or high levels of radiation and can possess wide range of application on industries [2]. Industrial processes often take place under harsh conditions that are hostile to microorganisms and their biocatalysts. Enzymes that are stable at high temperatures represent a chest of treasures for high-temperature bioprocesses. Hence microbial mats are excellent candidates for searching and studying such enzymes and their functions [3]. Highly specific heat resistant thermostable enzymes has considerable potential for different types of applications in food and dairy industries and its applications [4]. The proteins or enzymes of heat resistant organisms are more stable than normal or mesophillic bacteria. The thermostable enzymes are more resistant to chemical agents and hence considered highly suitable for different industrial process [5]. In these food and allied industries, thermostable proteases are considered due to their high withstanding $\mathrm{pH}$ conditions [6]. These thermostable protease producing microorganisms shall be isolated from natural [7] and manmade environment [8]. Microbial protease from thermostable bacteria has different important characteristics like expeditious growth, enormous diversity and easy genetic manipulation [9]. Hence a need to identify and isolate some novel bacteria and fungi capable of producing thermostable enzymes using inexpensive fermentation processes are highly considered [10, 11]. The aim of this research is to isolate the thermostable protease producing bacteria from microbial mats and to determine the in vitro and quantitative assay of protease enzyme activity. The enhanced production of thermostable protease under optimal conditions was considered another significant objective. Effect of carbon and nitrogen sources, inoculum size 
and temperatures are the different factors considered to select optimum conditions for enhance enzyme production in the present research.

\section{MATERIALS AND METHODS}

\section{Collection of microbial mats}

Microbial mats (Microbial mat-1 and Microbial mat-2) were collected from different places of Coimbatore. The mats were stored at frozen temperatures and used for further studies.

Isolation and Identification of thermostable protease enzyme producing bacteria from microbial mats

Screening for bacteria capable of producing Protease was performed using serial dilution of microbial mats on skim milk agar plates incubated at $37^{\circ} \mathrm{C}$. Bacterial colony forming zone of clearance on skim milk agar plates were isolated and purified using streaking methods [12].

\section{In Vitro Determination of enzyme activity - Thermostable protease assay}

The in vitro enzyme activity of thermostable protease was carried out using the method described by Jani et al. [13]. In brief, the bacterial cultures were placed on the center of skim milk agar media and incubated at different temperatures for $24 \mathrm{~h}$.

After incubation the plates were evaluated for zone of clearance. The relative enzyme activity (REA) was determined by using the formula:

\begin{tabular}{|ll|}
\hline \multirow{2}{*}{ REA $=$} & $\begin{array}{l}\text { Diameter of zone of clearance }(\mathrm{mm}) \\
\text { Diameter of the bacterial colony }(\mathrm{mm})\end{array}$ \\
\hline
\end{tabular}

\section{Quantitative assay of protease activity}

The quantitative assay of enzyme activity was carried out using the method described by Akcan and Uyar [14]. In brief, $0.5 \mathrm{ml}$ of casein and $1.25 \mathrm{ml}$ of tris buffer (pH-8.0) was 
added into $0.2 \mathrm{ml}$ of each of the culture supernatant separately. Mixture was incubated and $3 \mathrm{ml}$ of trichloroacetic acid was added to form precipitate. The absorbance was read at $660 \mathrm{~nm}$ and the obtained OD was extrapolated in the standard graph (bovine serum albumin as standard). One unit of protease activity was defined as the amount of enzyme required to liberate $1 \mu \mathrm{g} / \mathrm{ml}$ amino acid under the experimental conditions [14].

Enzyme activity $=$ OD value $X$ amount of protein released $(\mu \mathrm{g}) /$ concentration of substrate $X$ time of incubation $\mathrm{X}$ weight of the sample

\section{Optimization of conditions for enhanced enzyme production}

Different parameters were selected to optimize the cultural conditions like sources of carbon, nitrogen, temperature, and inoculum size. The actual fermentation was carried out in $100 \mathrm{ml}$ of the modified media inoculated with $10 \%$ of the inoculum of the first subcultures and incubated at $37^{\circ} \mathrm{C}$ at $180 \mathrm{rpm}$ for $48 \mathrm{~h}$. Among the microbial mat isolates, only ONE potential protein degrader $(1 \mathrm{~F})$ were selected from quantitative assay for the optimization studies [15].

\section{Effect of various carbon sources}

Casein broth was prepared with $1 \%$ of different carbon sources such as glucose, sucrose, lactose and maltose. Broths were inoculated separately with bacterial culture $1 \mathrm{~F}$ and incubated at $37^{\circ} \mathrm{C}$ for $48 \mathrm{~h}$. After the incubation period, protease activity was determined separately for the isolates inoculated in each carbon source.

\section{Effect of various nitrogen sources}

Casein broth was prepared with $1 \%$ of different nitrogen sources such as peptone, beef extract, yeast extract, ammonium sulphate and ammonium chloride. Broth was inoculated separately with bacterial culture $1 \mathrm{~F}$ and incubated at $37^{\circ} \mathrm{C}$ for $48 \mathrm{~h}$. After the incubation period, protease activity was determined separately. 


\section{Effect of various temperatures}

The effect of temperature on protease production was studied by taking different temperatures like $28^{\circ} \mathrm{C}, 37^{\circ} \mathrm{C}, 45^{\circ} \mathrm{C}$ and $55^{\circ} \mathrm{C}$. All the inoculated flasks were incubated at their respective temperatures for $48 \mathrm{~h}$ followed by protease activity was measured using spectrophotometer at $600 \mathrm{~nm}$.

\section{Effect of various inoculum size}

The effect of different inoculum size was optimized in the casein broth using the isolate, 1F. Sterile casein broth was prepared and inoculated with varying inoculum size of $1 \%, 2 \%, 3 \%, 4 \%$ separately by v/v. Uninoculated sterilized media was used as control. After incubation period, protease activity was determined using spectrophotometer at $600 \mathrm{~nm}$.

\section{RESULTS AND DISCUSSION}

\section{Isolation and Identification of protease enzyme producing bacteria from microbial mats}

About 6 organisms were isolated from Microbial mat-1 (1A, 1B, 1C, 1D, 1E \& 1F) (Fig. 1) and 5 microorganisms were isolated from Microbial mat-2 (2A, 2B, 2C, 2D \& 2E). From the 11 isolates, 6 organisms were found to produce zone clearance on the skim milk agar incubated at $37^{\circ} \mathrm{C}$. In Fig. 2, zone of clearance by the bacterial isolate (1F) on skim milk agar media was presented as representative example. Those pure cultures were stored as glycerol stocks and maintained on nutrient agar plates by sub-culturing every two weeks and used for enzyme activity at high temperatures.

\section{Thermostable protease assay}

The REA of the six isolates at different temperature was determined and presented in Table-1. Among the six isolates, $1 \mathrm{~F}$ showed maximum zone of clearance (REA > 5.0) at high temperatures $\left(55^{\circ} \mathrm{C}\right.$ and $\left.65^{\circ} \mathrm{C}\right)$. The zone of clearance of $1 \mathrm{C}$ at three different temperatures $45^{\circ} \mathrm{C}, 55^{\circ} \mathrm{C}$ and $65^{\circ} \mathrm{C}$ are $3.2 \pm 0.15 \mathrm{~mm}, 2.7 \pm 0.29 \mathrm{~mm}$ and $1.3 \pm 0.12$. $1 \mathrm{D}$ showed $1.5 \pm 0.40 \mathrm{~mm}$ at $45^{\circ} \mathrm{C}$ and no organism growth was recorded at $55^{\circ} \mathrm{C}$ and $65^{\circ} \mathrm{C} .1 \mathrm{~F}$ exhibited $2.2 \pm 0.26 \mathrm{~mm}$ at 
$45^{\circ} \mathrm{C}, 5.9 \pm 0.35 \mathrm{~mm}$ at $55^{\circ} \mathrm{C}$ and $5.3 \pm 0.27 \mathrm{~mm}$ at $65^{\circ} \mathrm{C}$ which was found to be higher on compared to other isolates at different temperature. $1 \mathrm{E}$ showed $5.1 \pm 0.17 \mathrm{~mm}$ zone of clearance at $65^{\circ} \mathrm{C}$ and $4.4 \pm 0.88 \mathrm{~mm}$ zone of clearance at $55^{\circ} \mathrm{C}$. $2 \mathrm{C}$ showed $3.7 \pm 0.09 \mathrm{~mm}$ at $45^{\circ} \mathrm{C}, 4.8 \pm 0.04 \mathrm{~mm}$ at $55^{\circ} \mathrm{C}$ and $4.8 \pm 0.04 \mathrm{~mm}$ at $65^{\circ} \mathrm{C}$. The zone of clearance of $2 \mathrm{D}$ at $45^{\circ} \mathrm{C}$ was found to be $1.1 \pm 0.34 \mathrm{~mm}$, no organism growth was observed at $55^{\circ} \mathrm{C}$ and $65^{\circ} \mathrm{C}$. Hence the protease produced by the $1 \mathrm{~F}$ is found to be stable even at high temperatures. From this study, it is proved that thermostable enzymes can be produced from the microbial mat colonies.

\section{Optimization of conditions for enhanced enzyme production}

The enzyme production was optimized under the selected parameters using the bacterial culture $1 \mathrm{~F}$ isolated from microbial mat-1. The amount of enzyme produced by the strain and its activity under each type of parameters are presented below.

\section{Effect of Carbon supplementation}

To determine the effect of each carbon source, casein broth was prepared and inoculated with bacterial culture 1F. After inoculation period, the enzyme was extracted, assayed and determined using $\mathrm{UV}-\mathrm{V}$ is spectrophotometer at $600 \mathrm{~nm}$. In Table-2 Maltose brought the highest enzyme activity about 462.3 (IU). Glucose brought the second highest enzyme activity about 257.5 (IU). Followed by Lactose showed 160.5(IU) and sucrose showed minimum enzyme activity about 39.6 (IU). The present findings also revealed that lactose was the best carbon source to induce the production of protease by Bacillus subtilis on production medium, expressing maximum productivity.

\section{Effect of various nitrogen sources/substrates on protease activity}

The effect of different nitrogen source on protease activity was determined from the culture inoculated casein broth. After incubation period, the enzyme extracted, assayed and determined using UV-Vis spectrophotometer was presented in below Table. In Table-3 results obtained showed that the yeast extract showed highest enzyme activity of 510.2 (IU). 
Peptone showed the second highest enzyme activity of 360.5 (IU) followed by ammonium chloride expressing 156.6 (IU). Ammonium sulphate showed minimum activity of about 89.5 (IU) by the test isolate $1 \mathrm{~F}$ during the analysis. Our results are in accordance to the findings of Krishna Ash et al., [12], who observed that growth medium containing peptone produced maximum protease. This was followed by yeast extract, tryptone, ammonium sulphate and ammonium chloride.

\section{Effect of various inoculum sizes on protease activity}

Inoculum size of the test bacterial isolate was studied to determine the protease activity. Different inoculum size added onto casein broth assayed for enzyme activity was presented in below Table. In Table-4, inoculum size (1\%) showed highest enzyme activity of 390.5 (IU). The $2 \%$ inoculum size showed the second highest enzyme activity of 155.6 (IU) followed by $3 \%$ expressing 75.5 (IU) and minimal activity of 20.2 (IU) in the media inoculated with $4 \%$ culture inoculum. Results from the present study showed that the optimum inoculum size of the bacterial isolate for protease production was $1 \mathrm{ml}$ from overnight culture broth. Similar observation has been reported by Gupta et al., [16], where an optimum inoculum size was $1 \mathrm{ml}$ from stock suspension for maximum protease.

\section{Effect of various temperatures on protease activity}

To determine the effect of temperature all inoculated flasks were incubated at different temperatures such as $28^{\circ} \mathrm{C}, 37^{\circ} \mathrm{C}, 45^{\circ} \mathrm{C}$ and $55^{\circ} \mathrm{C}$ for 24 to 48 hours. After the incubation period, standard protease assay was determined using UV-Vis spectrophotometer at $600 \mathrm{~nm}$. In Table- 5 results showed that the temperature about $45^{\circ} \mathrm{C}$ showed highest enzyme activity of about 437.5 (IU). At $37^{\circ} \mathrm{C}$, the second highest enzyme activity of 169.2 (IU) by the isolate was evident. At $28^{\circ} \mathrm{C}$ and $55^{\circ} \mathrm{C}$ about 385.6 (IU) and 16.8 (IU) of enzyme activity was found respectively. 


\section{CONCLUSION}

Isolation and production of thermostable enzyme producing bacteria from microbial mats was selected as a novel concept in the present research. As thermostable protease has more commercial value in different industries, the aim of this study was to search for such an enzyme producing bacteria from the microbial mats. Different parameters including cheap carbon and nitrogen substrates, inoculum size and temperature was selected to optimize the enzyme production conditions. Initially five different isolates from two microbial mats collected from different sources were analyzed for its ability to produce thermostable protease after exposing to higher temperature incubation conditions. Test culture tentatively named as $1 \mathrm{~F}$ from microbial mat-1 was selected as more enzyme producer among the ten isolates. The organism was selected based on the zone of clearance on skim milk agar by the isolate, that indicating more protease production. Under each optimization parameter, each type of carbon (Lactose), and nitrogen (yeast extract) source showed more enzyme production and activity respectively. About $1 \%$ inoculum size and a thermostable temperature of $45^{\circ} \mathrm{C}$ produced significant amount of enzyme and its activity. The obtained results emphasized the need for thermostable protease for different commercial industries in the existing and near future. Also the isolated bacteria $(1 \mathrm{~F})$ needed to be identified for the bulk production of protease using the selected optimized conditions. This step is considered as the future study of our research work.

\section{CONFLICT OF INTEREST}

Authors declare no conflict of research in the present work. 


\section{REFERENCES}

[1] Cristina MPB, Eduardo VC, Gustavo S. Microbial mat ecosystems: Structure types, functional diversity, and biotechnological application. Electronic Journal of Biotechnology. 31,$2018 ; 31: 48-56$.

[2] Hoehler TM, Bebout BM, Des Marais DJ, The role of microbial mats in the production of reduced gases on the early Earth. Nature. 2001; 412 (6844):324-327.

[3] Lun Wong H, Smith, DL, Visscher PT. Niche differentiation of bacterial communities at a millimeter scale in Shark bay microbial mats. Nature. 2015; 5:156-159.

[4] Haki GD, Rakshit SK, Developments in industrially important thermostable enzymes: A review. Bioresource Technology. 2003; 89(1):17-34.

[5] Lasa I, Berenguer J. Thermophilic enzymes and their biotechnological potential. Microbiologia. 1993; 9(2):77-89.

[6] Sakpal HC, Narayan G. Thermostable alkaline protease from Bacillus sp. and its potential applications. Journal of Pharmaceutical and Biological Sciences. 2015; 10:58-67.

[7] Chellapan S, Jasmin C, Basheer SM, Kishore A, Elyas KK, Bhat SG. Characterization of an extracellular alkaline serine protease from marine Engyodontium album BTMFS10. Journal of Industrial Microbiology and Biotechnology. 2011; 38:743-752.

[8] Peng Y, Huang Q, Zhang RH, Zhang YZ. Purification and characterization of a fibrinolytic enzyme produced by Bacillus amyloliquefaciens DC-4 screened from Douchi, A traditional Chinese soybean food. Comparative Biochemistry and Physiology - B Biochemistry and Molecular Biology. 2003; 134:45-52.

[9] Chatterjee S. Production and estimation of alkaline protease by immobilized Bacillus licheniformis isolated from poultry farm soil of 24 Parganas and its reusability. Journal of Advanced Pharmaceutical Technology and Research. 2015; 6:2-6.

[10] Pathak AP, Deshmukh KB. Alkaline protease production, extraction and characterization from alkaliphilic Bacillus licheniformis KBDL4: A Lonar soda lake isolate. Indian Journal of Experimental Biology. 2012; 50:569-576.

[11] Wilson P, Remigio Z. Production and characterisation of protease enzyme produced by a novel moderate thermophilic bacterium (EP1001) isolated from an alkaline hot spring, Zimbabwe. African journal of microbiology research. 2012; 6:5542-5551.

[12] Krishna Ash, Sushma, Alok Milton Lall, Rao KP, Pramod W. Ramteke. 2018. Production and Optimization of an Alkaline Protease from Acinetobacter variabilis Isolated from Soil Samples. International journal of environment, agriculture and biotechnology. 2018; 11(2): 379-386. 
[13] Jani SA, Chudasama CJ, Patel DB, Bhatt PS, Patel HN. Optimization of extracellular protease production from alkali thermo tolerant actinomycetes: Saccharomonospora viridis SJ-21. Bulletin of Environment, Pharmacology and Life Sciences. 2012; 1:84-92.

[14] Akcan N, Uyar F. Production of extracellular alkaline protease from Bacillus subtilis RSKK96 with solid state fermentation. EurAsian Journal of BioSciences, 2011; 5:64-72.

[15] Gitishree Das, Prasad, MP, Isolation, purification and mass production of protease enzyme from Bacillus subtilis. International Research Journal of Microbiology. 2010; 1(2):26-031.

[16] Gupta R, Beg QK, Lorenz P. Bacterial alkaline proteases: molecular approaches and industrial applications. Applied Microbiology and Biotechnology, 2002; 59:15-32. 
Fig. 1: Isolation of protease producing bacteria from microbial mat source

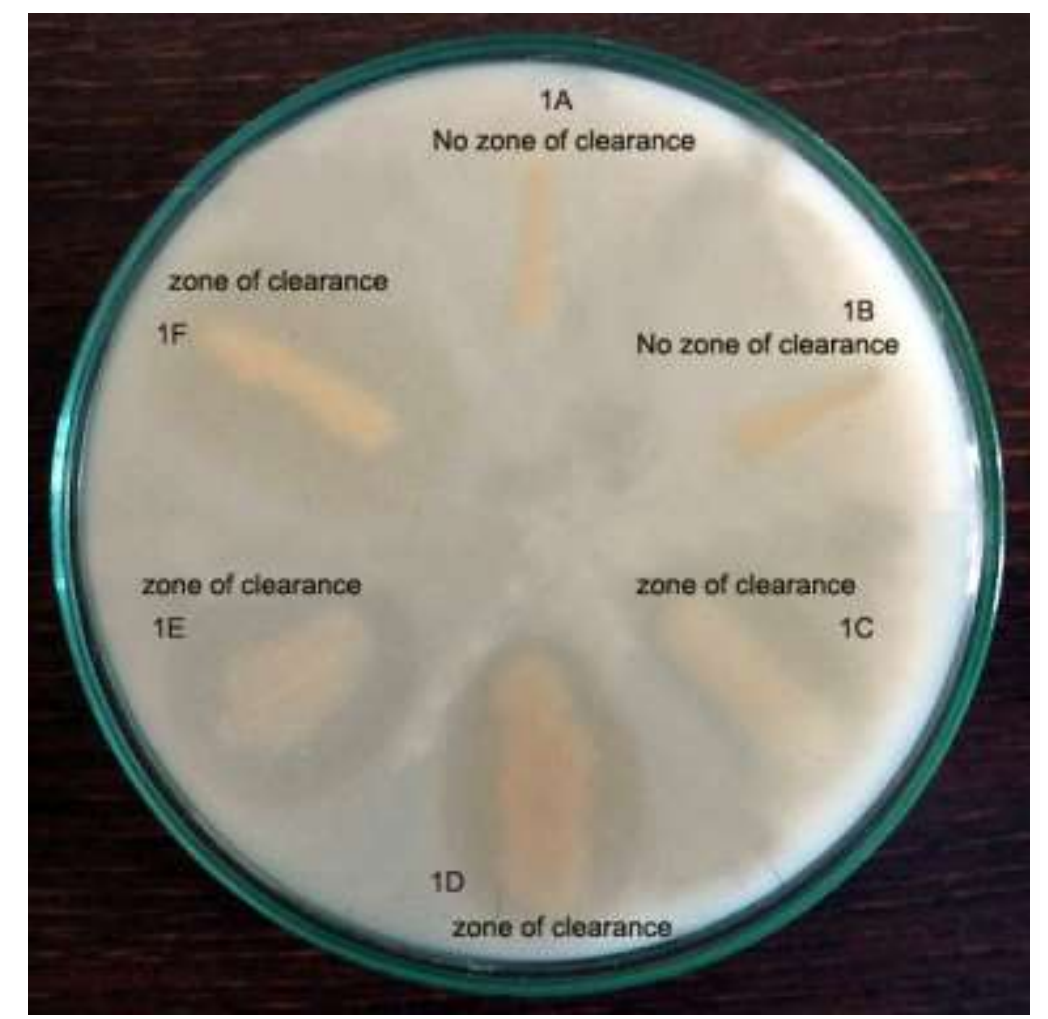

(Colonies showing maximum zone of clearance are selected $-1 \mathrm{~F}$ )

Fig. 2: Zone of clearance on Skim Milk Agar media by protease producing bacteria

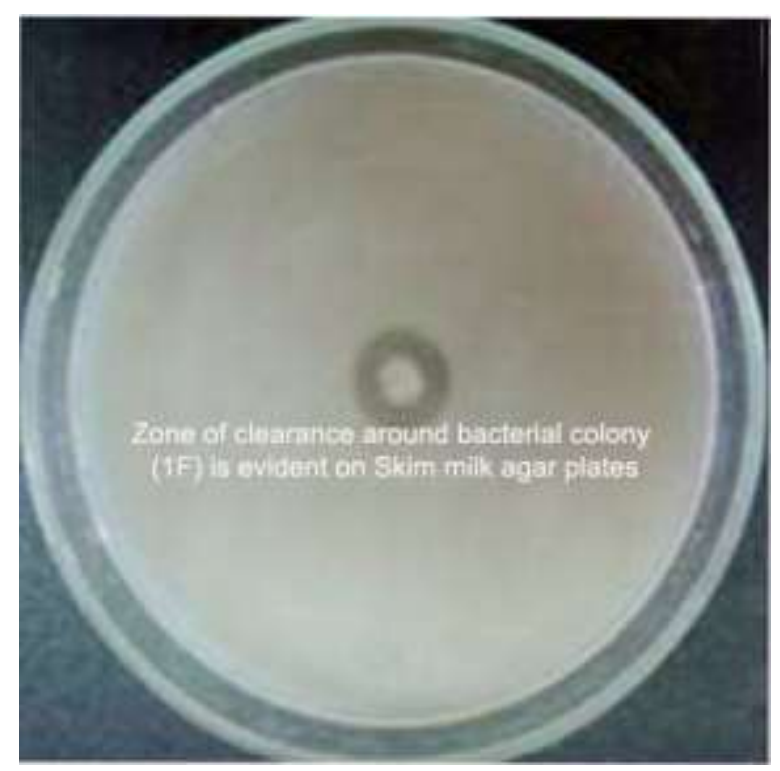

Zone of clearance around bacterial colony $(1 \mathrm{~F})$ is evident on Skim milk agar plates 
Table-1: In Vitro Determination of enzyme activity - Thermostable protease assay

\begin{tabular}{|c|c|c|c|c|}
\hline \multirow{2}{*}{ S.No } & \multirow{2}{*}{$\begin{array}{c}\text { Bacterial } \\
\text { isolates }\end{array}$} & \multicolumn{3}{|c|}{ Zone of Clearance at different temperatures (mm) } \\
\hline & & $45^{\circ} \mathrm{C}$ & $55^{\circ} \mathrm{C}$ & $65^{\circ} \mathrm{C}$ \\
\hline 1 & $1 \mathrm{C}$ & $3.2 \pm 0.15$ & $2.7 \pm 0.29$ & $1.3 \pm 0.12$ \\
\hline 2 & $1 \mathrm{D}$ & $1.5 \pm 0.40$ & - & - \\
\hline 3 & $1 \mathrm{E}$ & $2.1 \pm 0.13$ & $4.4 \pm 0.88$ & $5.1 \pm 0.17$ \\
\hline 4 & $1 \mathrm{~F}$ & $2.2 \pm 0.26$ & $5.9 \pm 0.35$ & $5.3 \pm 0.27$ \\
\hline 5 & $2 \mathrm{C}$ & $3.7 \pm 0.09$ & $4.8 \pm 0.04$ & $4.8 \pm 0.04$ \\
\hline 6 & $2 \mathrm{D}$ & $1.1 \pm 0.34$ & - & - \\
\hline
\end{tabular}

Table-2: protease activity at different carbon sources

\begin{tabular}{|c|c|c|c|c|}
\hline S. No & Carbon sources & $\begin{array}{c}\text { Optical density } \\
\text { value }\end{array}$ & $\begin{array}{c}\text { Amount of ptn } \\
\text { released (ug) }\end{array}$ & $\begin{array}{c}\text { Enzyme } \\
\text { Activity(IU) }\end{array}$ \\
\hline 1 & Glucose & 0.64 & 1210 & 257.5 \\
\hline 2 & Sucrose & 0.28 & 460 & 39.6 \\
\hline 3 & Maltose & 0.81 & 1590 & 462.3 \\
\hline 4 & Lactose & 0.52 & 980 & 160.5 \\
\hline
\end{tabular}

Table-3: protease activity at different nitrogen sources

\begin{tabular}{|c|c|c|c|c|}
\hline S.No & $\begin{array}{c}\text { Nitrogen } \\
\text { Sources }\end{array}$ & $\begin{array}{c}\text { Optical density } \\
\text { value }\end{array}$ & $\begin{array}{c}\text { Amount of ptn } \\
\text { released (ug) }\end{array}$ & $\begin{array}{c}\text { Enzyme } \\
\text { Activity (IU) }\end{array}$ \\
\hline 1 & Peptone & 0.79 & 1250 & 360.5 \\
\hline 2 & Yeast extract & 0.94 & 1460 & 510.2 \\
\hline 3 & Ammonium sulphate & 0.38 & 620 & 89.5 \\
\hline 4 & Ammonium chloride & 0.51 & 910 & 156.6 \\
\hline
\end{tabular}

Table-4: Protease activity at different inoculum sizes

\begin{tabular}{|c|c|c|c|c|}
\hline S.No & Inoculum size & $\begin{array}{c}\text { Optical density } \\
\text { value }\end{array}$ & $\begin{array}{c}\text { Amount of ptn } \\
\text { released (ug) }\end{array}$ & $\begin{array}{c}\text { Enzyme } \\
\text { Activity (IU) }\end{array}$ \\
\hline 1 & $1 \%$ & 0.79 & 1250 & 390.5 \\
\hline 2 & $2 \%$ & 0.55 & 950 & 155.6 \\
\hline 3 & $3 \%$ & 0.32 & 610 & 75.5 \\
\hline 4 & $4 \%$ & 0.19 & 290 & 20.2 \\
\hline
\end{tabular}


Table-5: Protease activity at different temperatures

\begin{tabular}{|c|c|c|c|c|}
\hline S. No & Temperature & $\begin{array}{c}\text { Optical } \\
\text { density value }\end{array}$ & $\begin{array}{c}\text { Amount of ptn } \\
\text { released (ug) }\end{array}$ & $\begin{array}{c}\text { Enzyme } \\
\text { Activity (IU) }\end{array}$ \\
\hline 1 & 28 & 0.50 & 910 & 145.5 \\
\hline 2 & 37 & 0.84 & 1250 & 385.6 \\
\hline 3 & 45 & 0.20 & 390 & 25.3 \\
\hline 4 & 55 & 0.16 & 280 & 16.8 \\
\hline
\end{tabular}

